\title{
Figurative Elements in Mosaics and Roman Painting at Algarve (Portugal)
}

\author{
Algarve'daki (Portekiz) Mozaikler ve Roma Resimleri \\ Üzerindeki Figüratif Unsurlar
}

João Pedro BERNARDES*

(Received 01 November 2016, accepted after revision 26 April 2017)

\begin{abstract}
The figurative mosaics with marine fauna at Algarve region, in the south of Portugal, are various and well known, particularly from Roman villa of Milreu. But connected to the sea there are also human representations in the mosaics of the region which, such as the marine themes, are characterized by a strong stylistic link to the Roman art of the North Africa. Recently both figurative themes, animal or human, also arise in parietal painting of the Algarve, specifically in a maritime villa specialized in fish-salting with strong North African links well attested by pottery import profile. This paper aims to explore affinities with both types of artistic representations in the region south of the former province of Lusitania, as well as to see North African links.
\end{abstract}

Keywords: Figurative mosaics, marine fauna, mural painting, human motifs.

\section{Öz}

Portekiz'in güneyindeki Algarve Bölgesi'nde deniz canlılarının betimlendiği figüratif mozaikler büyük çeşitlilikte olup, özellikle Milreu'deki Roma villası'ndan tanınmaktadır. Fakat denizle bağlantılı olarak, deniz temalarının işlendiği bölge mozaiklerinde insan tasvirleri de görülmektedir. Bu durum, Kuzey Afrika'nın Roma sanatı ile güçlü bir üslup bă̆lantısı olduğunu gösterir. Son zamanlarda, Algarve’nin paryetal resimlerinde yer alan hem hayvan hem de insan tasvirlerinin oluşturduğu figürlü konular, özellikle deniz klyısında bulunan ve kurutulmuş balık ticareti yapan villanın Kuzey Afrika ile güçlü bir bağlantısının olduğunu göstermektedir. Bu çalışmada, Kuzey Afrika bağlantılarının yanı sıra, eski Lusitania Eyaleti'nin güneyi ile olan bă̆lantılarının da araştırılması amaçlanmaktadır.

Anahtar Kelimeler: Figürlü mozaikler, deniz faunası, duvar resmi, insan betimleri.

\section{The Algarve region and the figurative mosaics}

In the Portuguese region of the Algarve, which corresponded to the South of the former province of Lusitania, there are more than 40 sites with Roman mosaics, although most is only known by small fragments or tesserae. Indeed, only about twenty sites have mosaics or fragments with conserved motifs. Most of these floors show geometric or vegetal motifs and only six are elements figured (Fig. 1). These are related to the sea, especially with marine animals. The villa of Milreu is the only place where there are multiple murals panels with these themes. On the others sites the mosaics are floors. The realistic representation and variety of marine fauna allows identifying several local species. All the figured mosaics are late, dating from the end of the second century AD or the beginning of the third $\mathrm{AD}$, when the region of the Algarve had a big economic development associated with fishing and export

\footnotetext{
* João Pedro Bernardes, Universidade do Algarve - CEAACP, Faro, Portugal. E-mail: jbernar@ualg.pt
} 


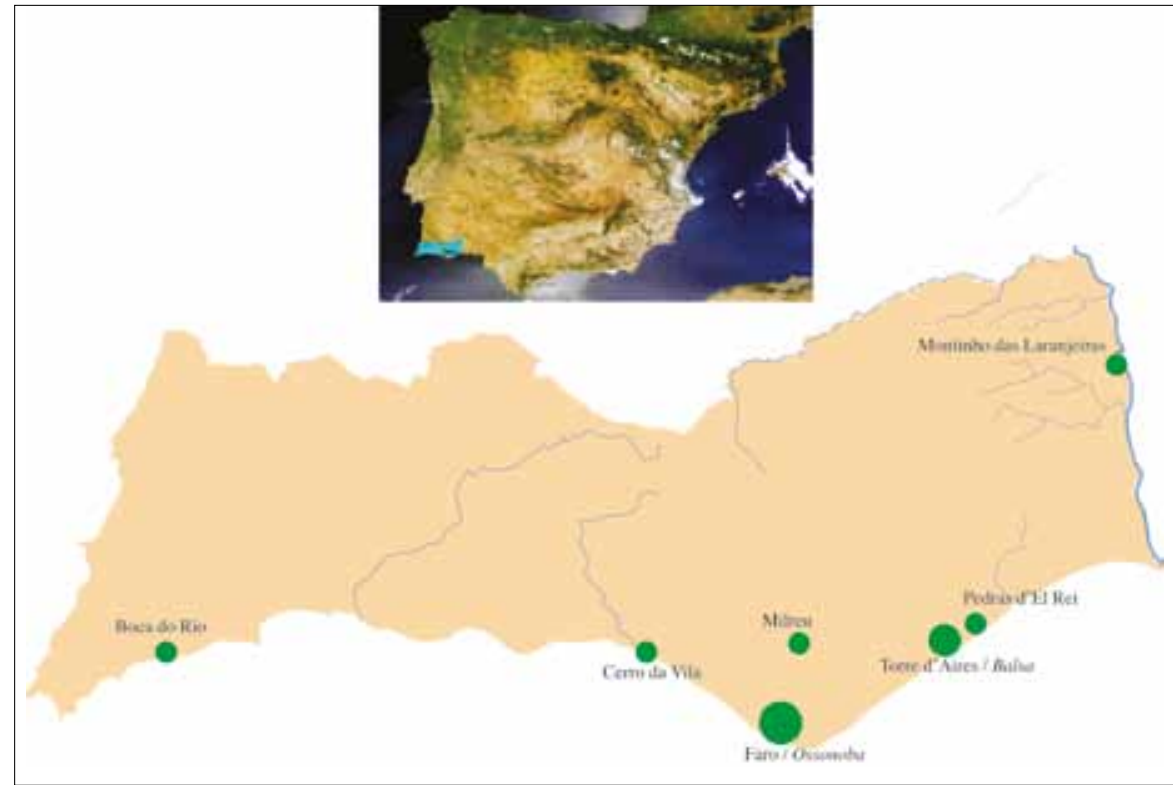

Figure 1

Roman sites at Algarve

(South of Portugal) with figurative art (referenced in the text).

of fish-salting. In fact, along the coast of the region we can identify some thirty sites directly related to the exploitation of marine resources (Fig. 2). But some of the villas nearby the coast could keep also some establishments linked to the fishing and fish-salting process. It is possible that this has been the case of Milreu and other roman villas, located less than a dozen kilometres from the coast, which complemented the farming income with very lucrative activities connected to the production and export of the fish-salting. These villas, although they were not directly on the coast, would be linked to some seasonal coastal

Figure 2

Roman sites at Algarve

(South of Portugal) with fish-salting units (cetariae)

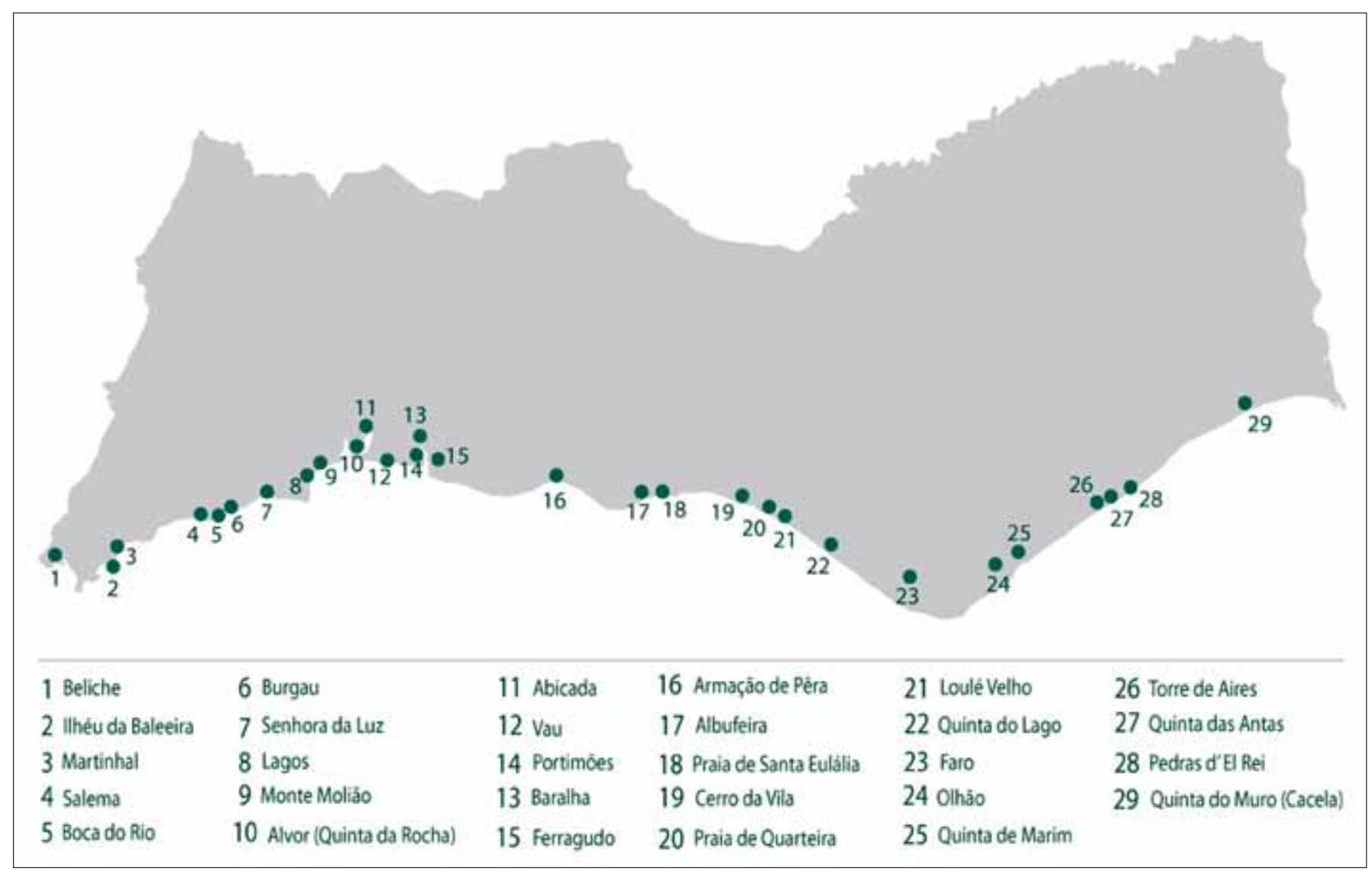




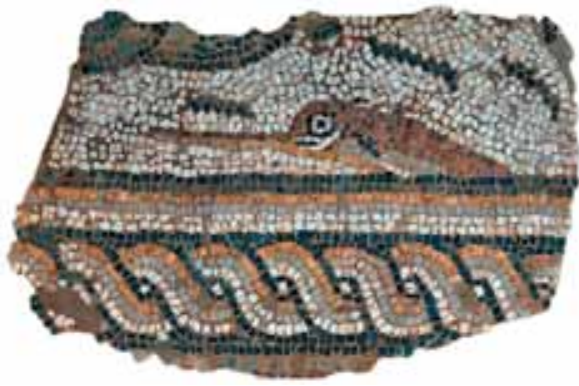

Figure 3

Swordfish in a mosaic of Montinho das Laranjeiras.

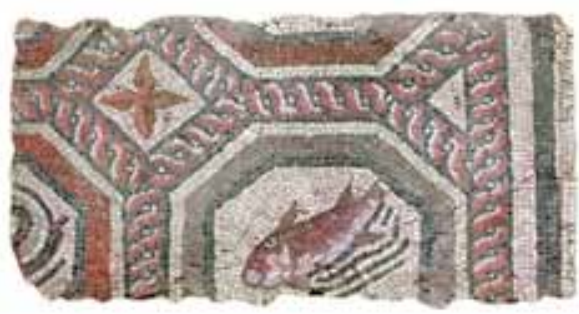

Figure 4

Fish swimming fast in a mosaic of Pedras d'El Rei.

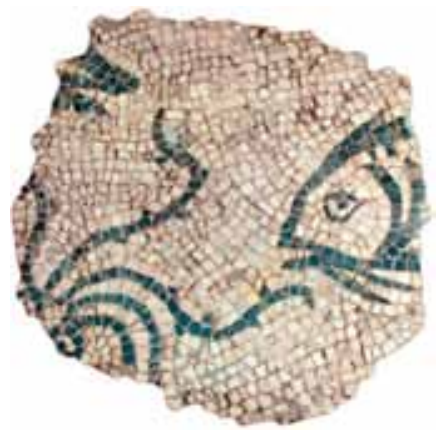

Figure 5

Fish and octopus in a mosaic of Torre de Aires

(Lancha-Oliveira 2013). establishments wich are archaeologically marked by cetariae (vats), but without being integrated into housing complexes unlike officinae cetariorum of the maritime villas. In this territory in the South of the province of Lusitania, where fertile land is scarce but where the sea is exceptionally abundant in fish, the rich elites owners of the inland villas, certainly wanted to participate and invest in the negotium of the fish. The importance of marine resources for the local economy, seems to relate to the fact that the only figured motifs of the region are linked to the sea. Though with very different techniques qualities, all the mosaics have struggled for representing marine fauna and realistic live scenes. It's not so much the fish per se that represents, but more the diversified and living environment of the ocean, i.e. the nature as a source of resources and prosperity.

\section{The marine fauna and human figures in the mosaics}

There are several stylistic and technical features used to figure these living marine environments. In the case of the villa of the Montinho das Laranjeiras, located on the right bank of the Guadiana river, that allowed the oceanic navigation to deep inside the territory, we can see a swordfish on the move. To create the sensation of movement it was drawn the head and part of the body of the fish above the line that symbolizes the surface of the water. To create the sensation of moving water, tried to represent it in perspective, putting over the fish some blue lines representing the flow of the river (Fig. 3). This mosaic dates from the $5^{\text {th }}$ century or the $6^{\text {th }}$ century $\mathrm{AD}$, one of the later the region, revealing low technical expertise. However, the concern of the artists to create the sensation of movement is clear and common to the mosaics of other sites. Such is the case of the mosaic of Pedras d'El Rei, a maritime villa associated with a complex of fish preparations (Santos 1972: 307-317; Viegas - Dinis 2010). Here is given a feeling of quick fish movement through its diagonal position in the middle of an octagon, as if the fish dive, and, above all, by a succession of rows under the belly. These lines are wavy, overlapping and sometimes start in the fins creating that feeling of fast moving (Fig. 4).

The figurative elements on the diagonal position or the existence of wavy lines to create the sensation of movement are also present in Torre d'Aires and Cerro da Vila mosaics (Figs. 5-6). In Torre de Aires, the ancient city of Balsa, the tentacles of an Octopus move freely in front of a fish; in Cerro da Vila a cuttlefish with well-designed tentacles moves in the opposite direction to that of three fish and some molluscs. In the mosaic of the Cerro da Vila we can see also a Trident on the head of a fish, a dolphin, implying that the mosaicist wants to represent not only the living nature tout court, but its exploitation while economic resource. Here there wasn't need represent the water since it was present. Indeed, this panel of marine fauna occupied a bottom of a tank, probably a fountain or a nymphaeum (Teichner 2008: 343-344), and it was intended to be seen across the water. Such as the mosaic of Torre d' Aires, it is a monochrome Panel. Janine Lancha based on stylistic criteria in presence, which deviate from the Italian tradition, gives it a dating of the $4^{\text {th }}$ century AD (Lancha - Oliveira 2013: 460).

But it is in Villa of Milreu that realism and also the artistic quality, linked to the North African officinae, recurrently reaches its highest point at the region. Milreu is one of the most emblematic Roman sites of southern Lusitania, located about 4 miles from the sea although, as we have seen, has likely maritime interests. The figurative motifs of the mosaics from the villa are all of maritime scenes, and the fish are the decorative elements that dominate the semi-public spaces of the villa, such as the peristyle, the baths or on the podium decoration 


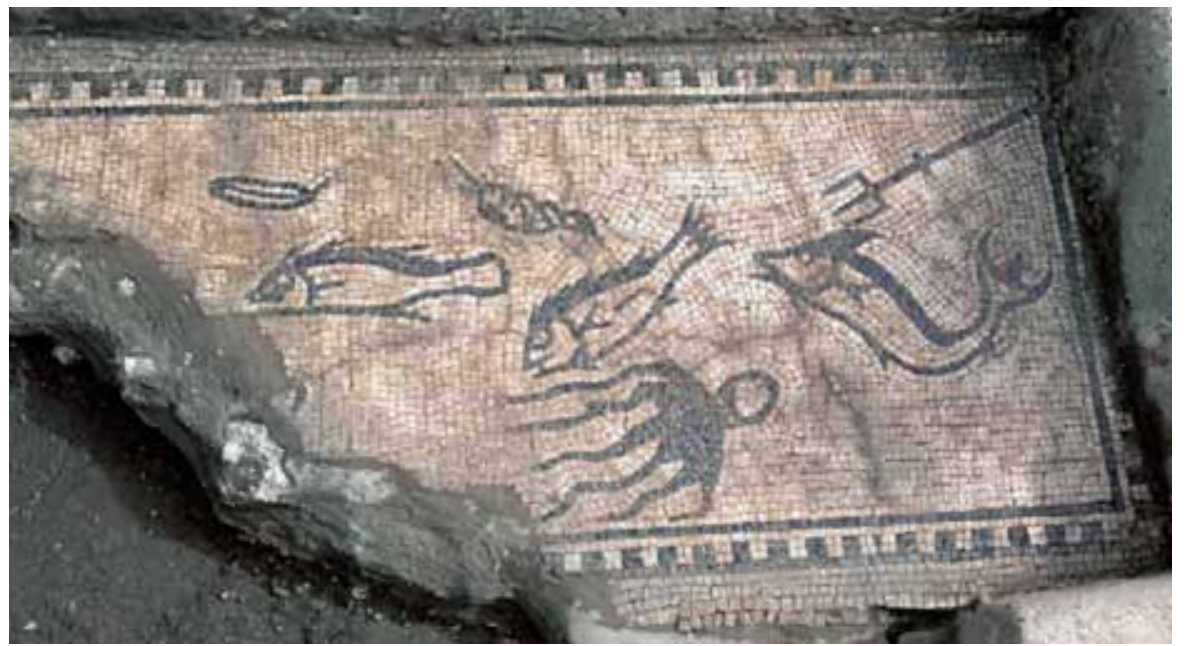

of the temple. These mosaics can be dated to the $4^{\text {th }}$ century $\mathrm{AD}$, revealing a great technical quality and a huge realism (Lancha - Oliveira 2013: 224-420). This realism allows in a lot of cases clearly identify the species of fish that are represented there, which correspond to a part of the marine fauna of the region. However, the most common and poorest fish, like mackerel or sardines, are not represented. The ichthyological analyses to the remains of fish found in the archeological record show that either the sardine or mackerel were abundantly fished and constituted most of the exported fish products. But, as today, these small fish were very common and low-price quote, serving for making common products or, according to Columella, food for the most valued species created in vivaria (R.R. VIII, 17, 11-15). Maybe that's why they have been deprecated by richer and finer fish, with greater economic value, and that fit much better in the language of ostentatious of the Roman villas and their elites. As a space of representation of the power and wealth of the owner that the late Roman villa aims to be, what is represented are mostly marine species known at the tables of the elites who visited the villa, or with a great commercial value.

The different species are always presented in a setting full of life and movement. Each mosaic panel is carefully chosen depending on the compartment where intended to be placed. Also the distribution of fauna in each panel is placed taking into account the position of the spectator. In a panel located on the northeast corner of the peristyle, one of the most notable mosaics at the site, a huge wealth of marine fauna is designed, swimming in multiple directions and with the bellies oriented down or up (Fig. 7). The panel is located in the peristyle at the door of access to one of the richest dependencies throughout the villa. It was, therefore, a central point in the communicational strategy and social representation of the entire residence, in order to be seen by guests to whom it was directed this manifestation of wealth. The goal of such variety was the marine scenery could be seen and also understood by everyone independently of the position of the viewer: for those who circulated in the peristyle, who entered in the reception room or who came out of this room to the peristyle. In this mosaic the arrangement of its elements is distributed according to the architectural context. It is a clear example of how the study of this kind of floors cannot be made without taking into account the architectural space where they belong and for which they were designed.

The huge variety of marine species is not just to fish. Molluscs, clams, stars and sea urchins alternate with fish of various species and sizes. The marine species 


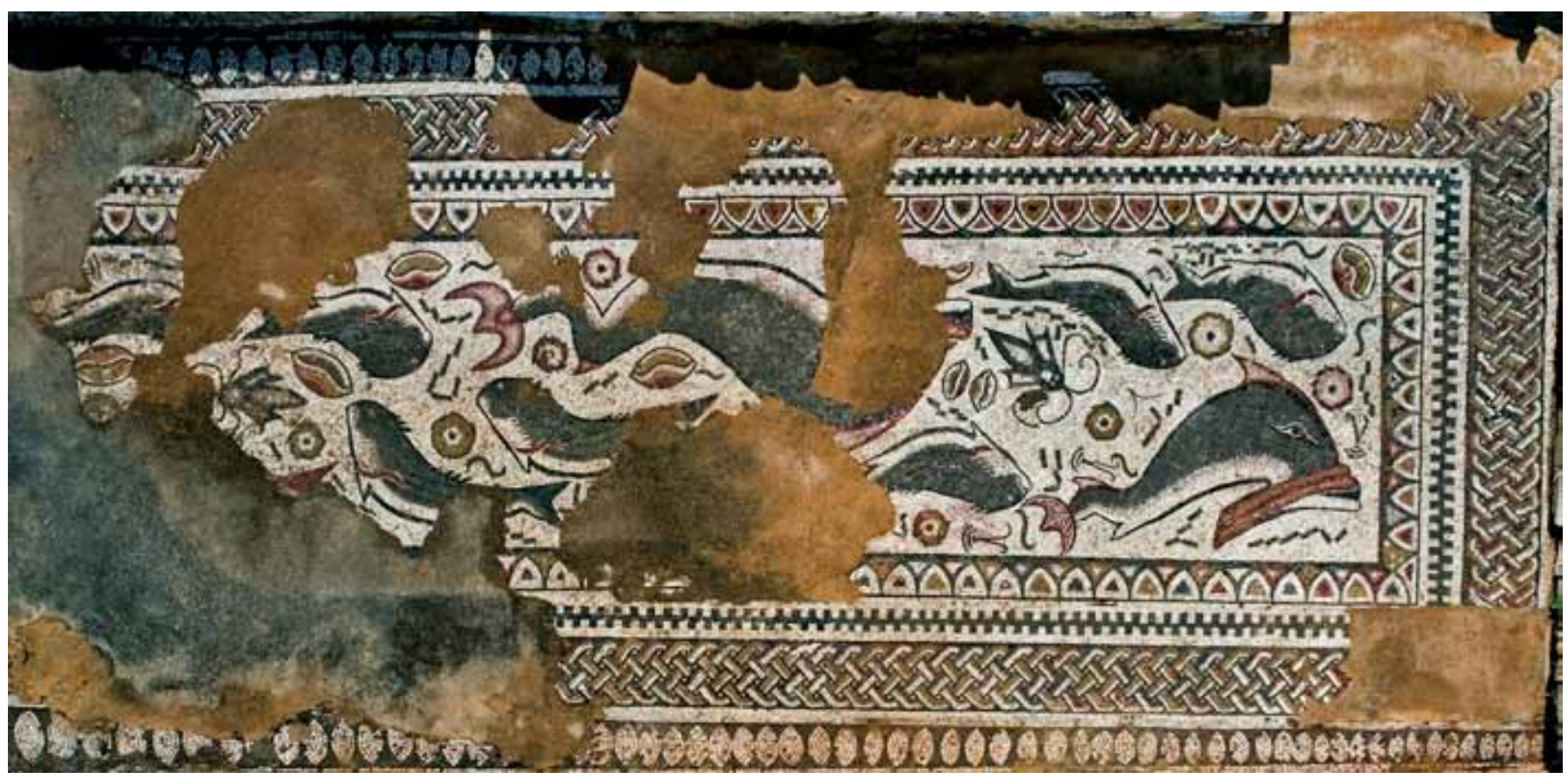

Figure 7

Panel of the villa of Milreu representing the marine life that can be seen from various perspectives.

Figure $8 \mathrm{a}-\mathrm{b}$

Details of the previous panel of the villa de Milreu. The realism and variety of marine species are characteristic of mosaics of the Algarve (Lancha-Oliveira 2013). are designed with great technical quality and realism allowing to recognize easily dolphins, anchovies, gilthead seabream etc. which swim among sea urchins, bivalves, squids and other marine elements (Figs. 8a-b). The dolphin is represented in stylized form although with great technical mastery, such as one of the squids that Janine Lancha ranked as the star of the mosaic (Campos Carrasco et al. 2008: 97). The African influence of the best schools of the Tunisia is well evident. Throughout the painting the water where the fish swim is represented by small lines. The species represented are characteristics of the marine fauna of the region with great economic value. It should be noted, for example, that in the Diocletian edict maximum of Prices (Edictum de Pretiis Rerum Venalium), dating from the year AD 301, a hundred oysters cost 100 denarii, and the price for only one good quality marine fish was fixed at 24 , while several mackerels or sardines only cost 16 denarii.

These realistic representations in scenarios that contain more idealized representations are also well present on the podium of the temple. Here is repeated the mastery of previous panel with dolphins, seabass, common seabream and
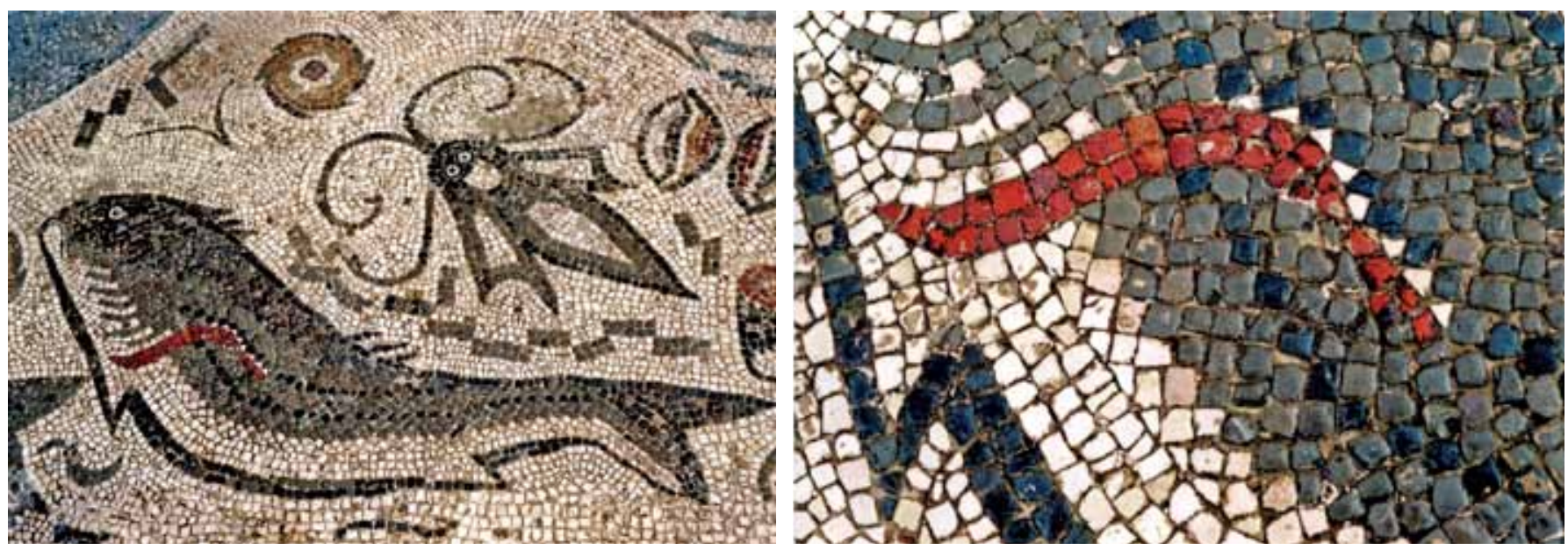


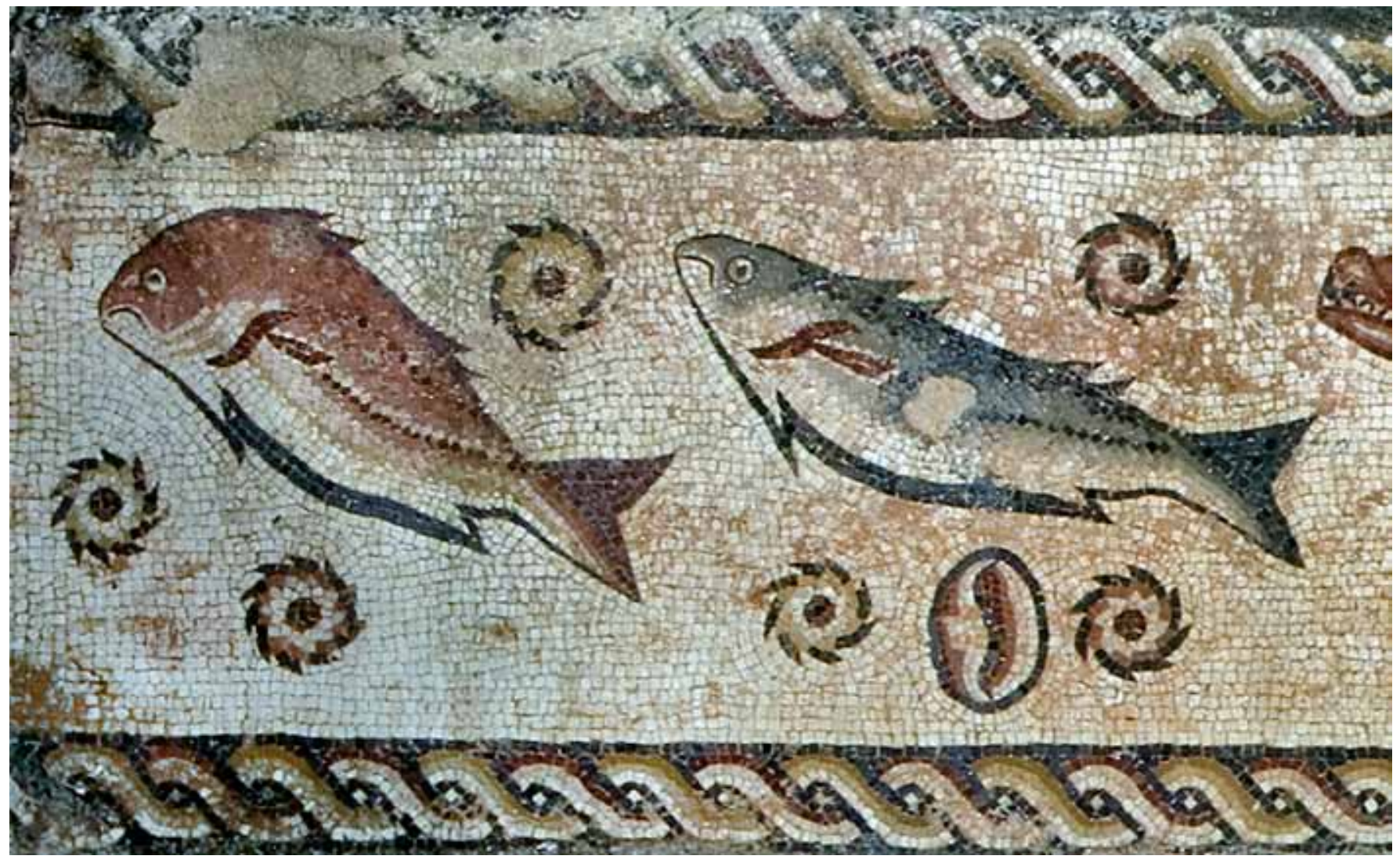

other species realistically figured among sea urchins and shellfish (Fig. 9). This realism goes so far as to seek respect the colors of the fish, as happens for example with common seabream pictured with salmon-colored pieces (tesserae) that identify clearly the color of this fish. In one of the walls of the podium of the temple is still possible to see a female foot, maybe a nereid; in another wall is represented a boat as that demonstrating that such marine wealth was exploited (Figs. 10a-b); marine centaurs are also present, alluding to the unknown sea where mythological figures live. The different plans aimed at so represent the sea in its different dimensions where the real and the imaginary (or unknown) are present.

These maritime representation scenarios appear also in a pool (frigidarium) of the baths. Not having the technical quality of the previous panels, the effort to realism is evident, and the common seabream are also represented with salmoncolored tesserae (Lancha - Oliveira 2013).

In Milreu figurative human motifs are only known in the female foot and on semi human figures of tritons or marine centaurs. But the mosaics in the Algarve have the most beautiful human representations in the mosaic of the Ocean. This is a panel belonging to the ancient city of Ossonoba (Faro) and decorated a floor of a schola navicularii, or any collegium of people connected to the sea. According to the inscription that has on the side where the door of the room was located, it was paid by 4 elements of that Association (Mantas 1990). For J. Lancha, which dates the mosaic from the late 2 nd century or early 3rd century A.D., the 4 donors identified would be probably the magistrates of the city (Lancha 1985; Lancha - Oliveira 2013: 222-223). The large panel has an emblema with the head of the ocean and the 4 winds, what approach it of several examples of Tunisia with the same theme (Fig. 11). With great realism and chromatic variety,
Figure 9

Detail of a panel from the podium of the Temple of Milreu. A common seabream and a sea bass are represented (Lancha-Oliveira 2013). 

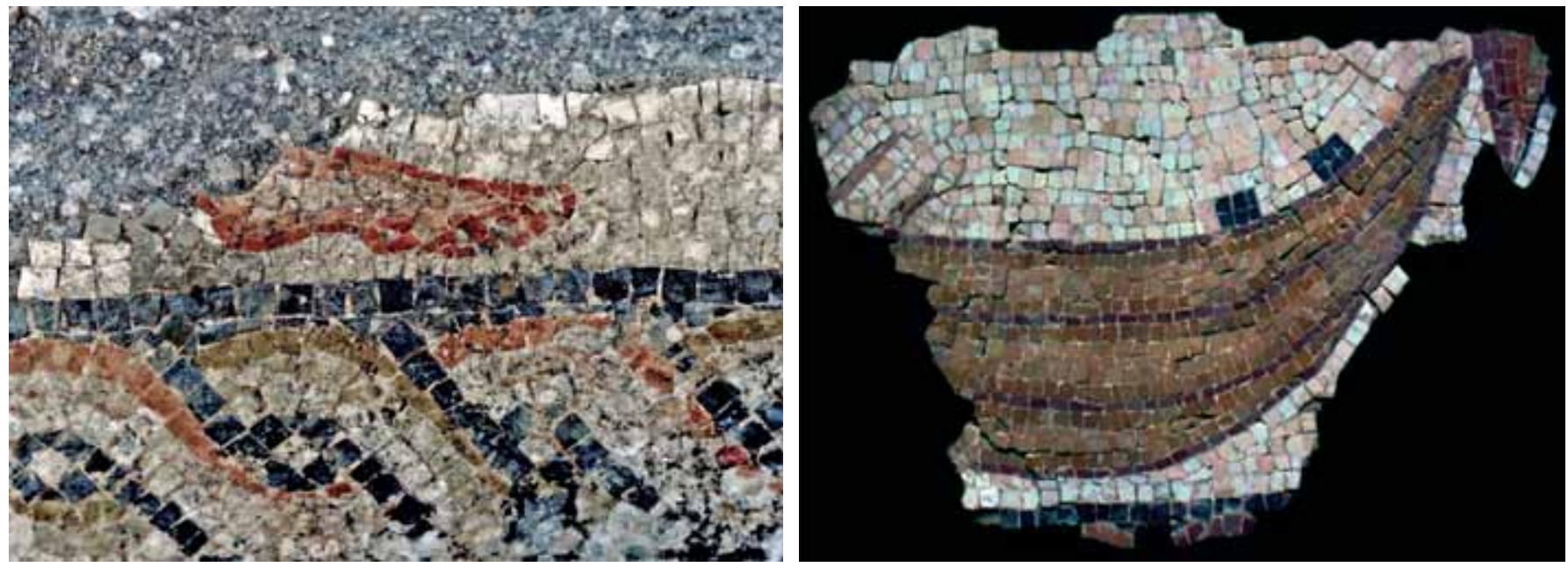

Figure $10 \mathrm{a}-\mathrm{b}$

A female foot and a boat from the podium of the Temple of Milreu.

Figure 11

The emblema of the Ocean Mosaic from Faro (Lancha - Oliveira 2013).

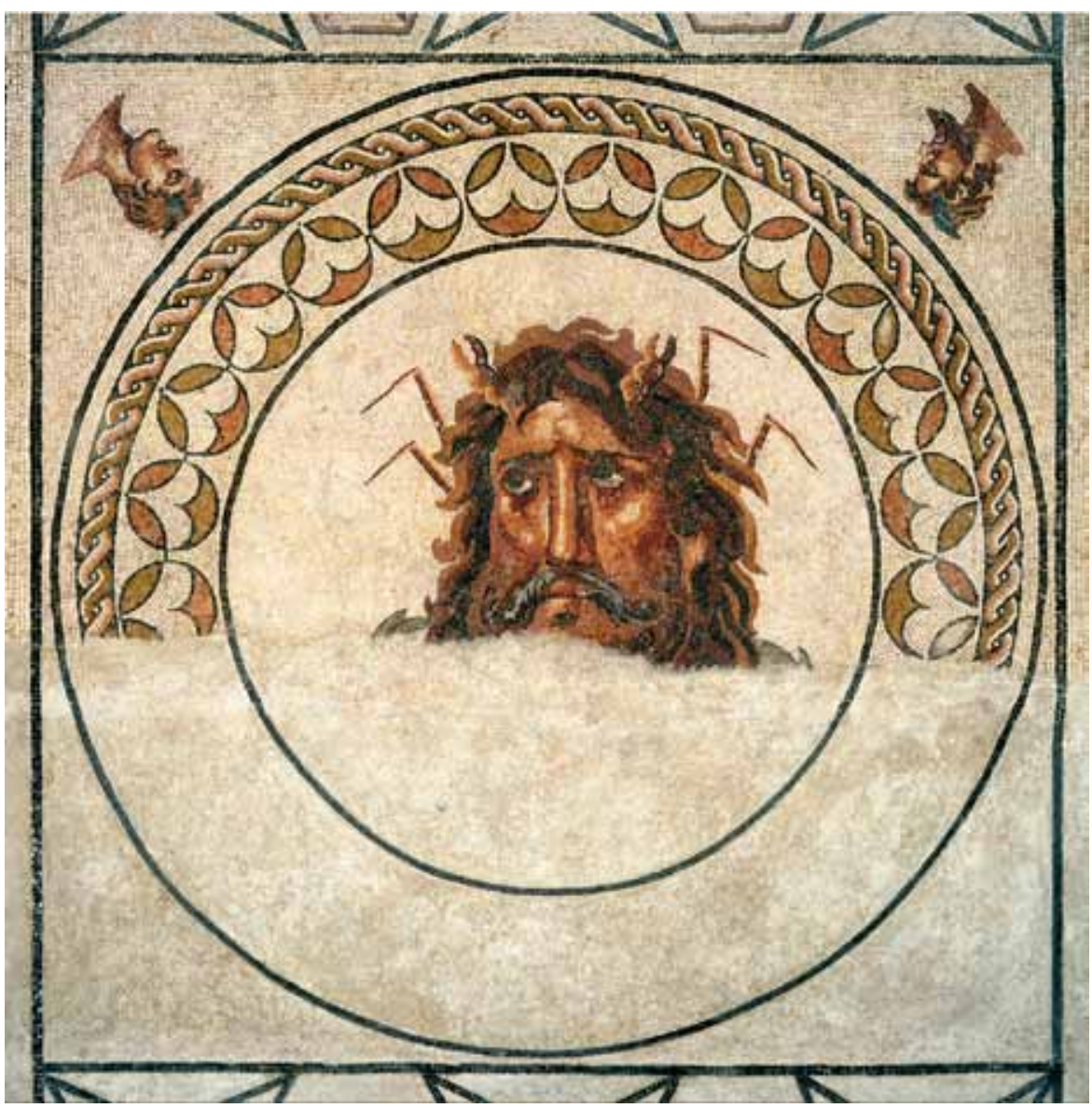

achieved through glass tesserae, the mosaic of Faro is the only one with representations of human faces in the Algarve region. The large central figure of the Ocean was surrounded at the corners by the 4 winds of which survive only two winds at the top of the figure. The wind from the left side of the head represents Zephyrus, the West wind (Fig. 12a). The representation of Zephyrus at the left side of the panel is not random because if we take into account the North South orientation of the panel in situ, we note that the Zephyrus head was located on the side where this wind was blowing (the West). The other wind represented is Boreas, the North wind, Zephyr's brother, located on the northeast corner of the 

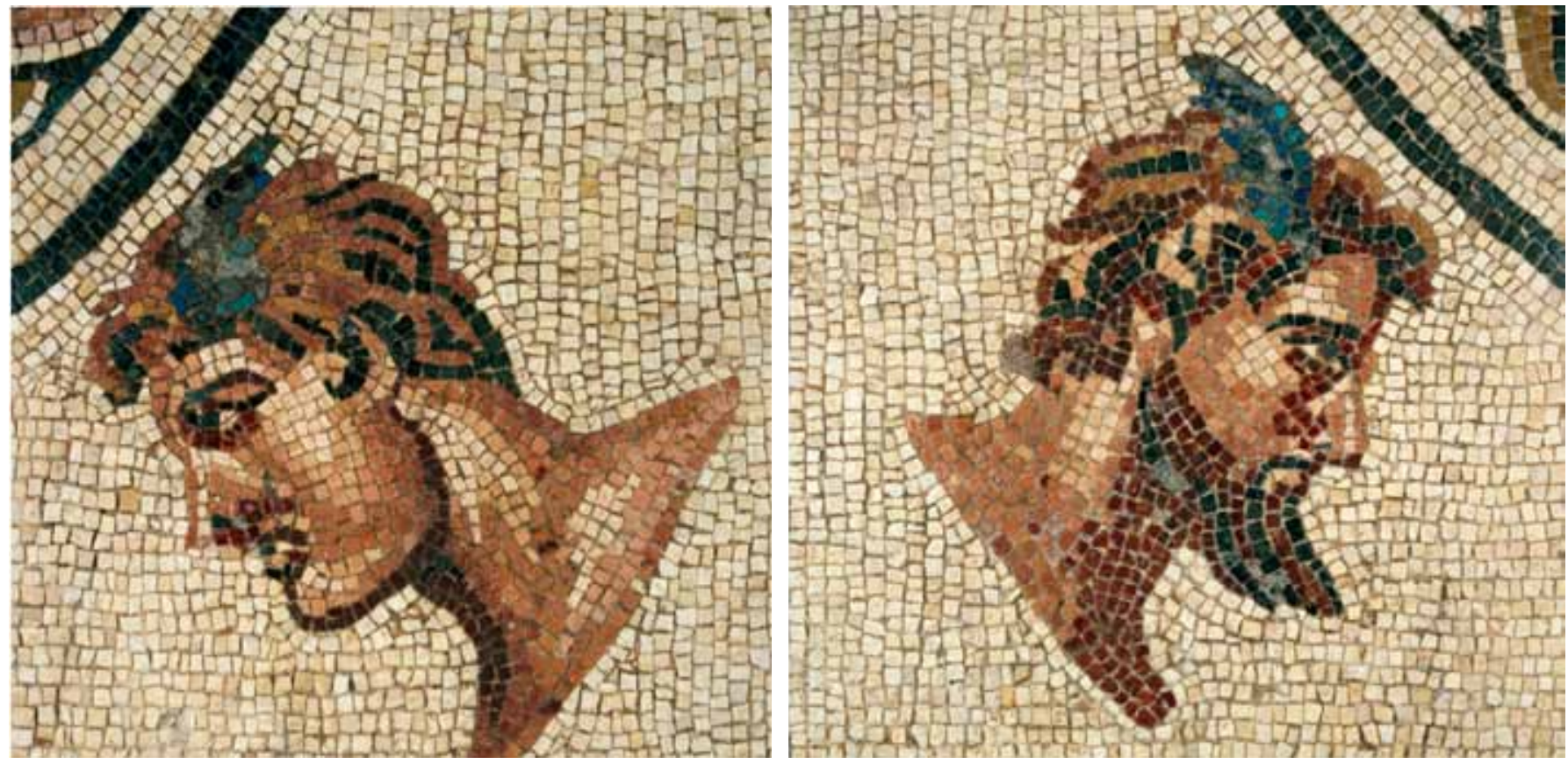

central emblema of the Ocean's head (Fig. 12b). On the South side of the panel should be Notus, the South wind, and Eurus, the East wind. Once again, this panel has a strong maritime connotation, although not related to the marine life but with navigation and commercial activities that characterized the port town of Ossonoba (Bernardes 2014).

\section{Human and animal representations in mural painting}

The human figure is also portrayed by mural painting, specifically on the site of Boca do Rio. The parietal painting, less known in the region than the mosaics, though it is as often as they are, have to be seen as part of the same decorative grammar where was the mosaic floors. Boca do Rio was a maritime villa dedicated almost exclusively to exploration of fish-salting preparations between the 1 st and $5^{\text {th }}$ century AD. Like other maritime villas of the region, such as that of Abicada, had a rich seafront accommodation while the officinae cetariorum were organized in their backyard. This model of villa, who favored a visual relationship with the ocean, reminds the maritime-villa that Pliny the younger had in Laurens, near Rome. According to the description that makes in a letter to Gallo (Epist. II, 17), was a single-storey villa, with a long narrow plan featuring a large balcony that was contemplating the sea.

Although there are several mosaic pavements of this villa (Santos 1971: 78106) they are with geometric or vegetal motifs. But these mosaics were closely articulated with a parietal art which was frequently renewed. This is what occurs in one of the rooms of the villa with stucco painted on the walls that are renewed at least six times between the end of the $2^{\text {nd }}$ century or early $3^{\text {rd }}$ century AD and the first half of the $5^{\text {th }}$ century AD (Bernardes - Medeiros 2016). Throughout this period of more than 200 years the mosaic with geometric motifs remained the same, even if it has been much rebuilt (Fig. 13). The geometric motifs of the mosaic allowed and facilitated, over time, the decorative coherence between the floor and the different pictorial programs of the walls. This constant renewal of the decorative walls of this room was not only to keep in good condition this area connecting the baths to the hall of the residential part of the villa. It was also a 

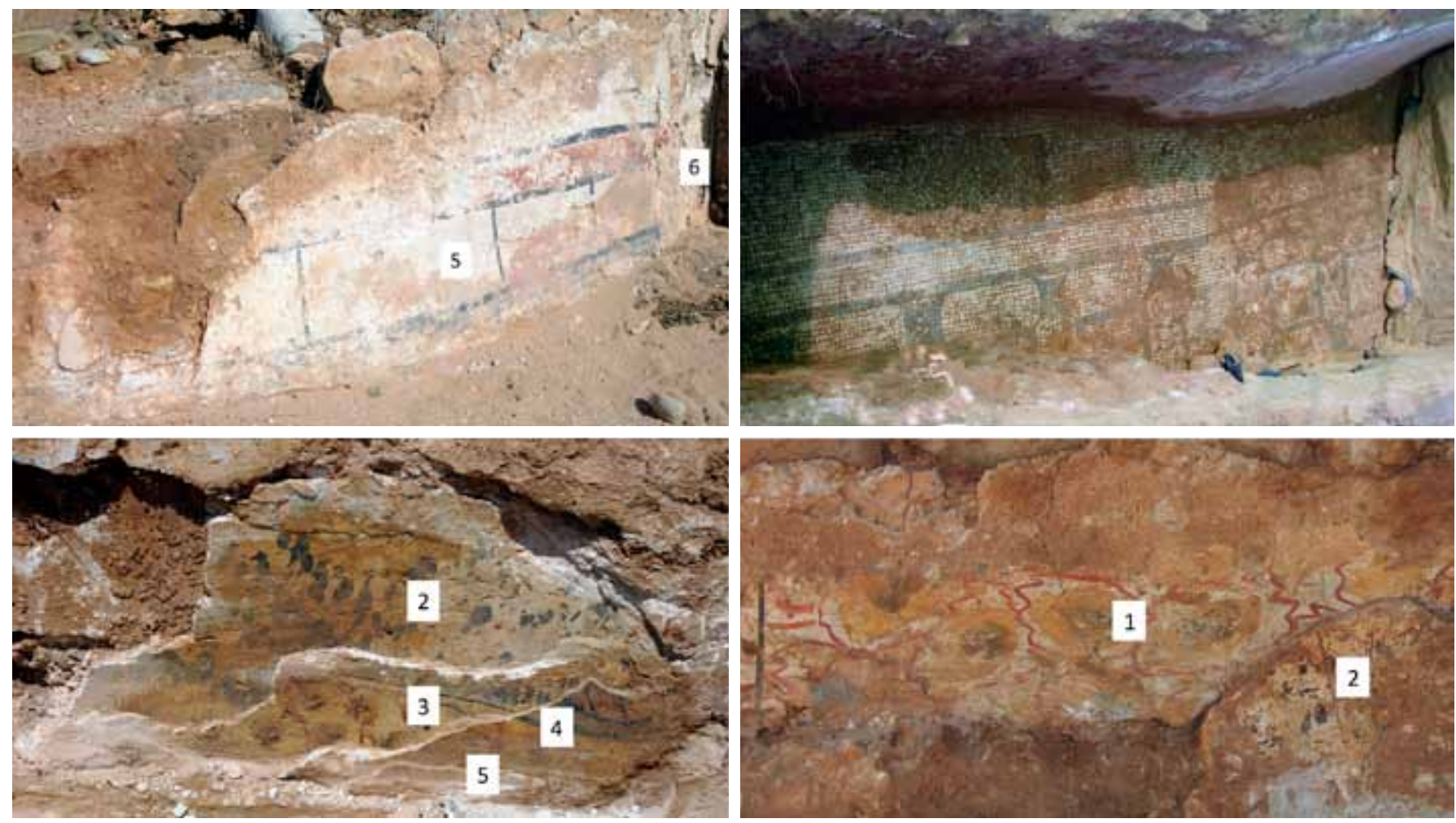

Figure 13

The six overlapping layers of stucco painted in a compartment of Boca do Rio (1- end of the $2^{\text {nd }}$ century/ beginning of the 3rd century AD; 6 - First half of the $5^{\text {th }}$ century AD). The mosaic of this compartment has remained the same for over 200 years.

Figure $14 \mathrm{a}-\mathrm{b}$

Human figure and a horse of a mural Painting of Boca do Rio (end of the $4^{\text {th }}$ century AD). way to renew and update the different decorative preferences of the domini, according to the image that they intended to pass through art in a semi-public area of the house.

At the end of the $4^{\text {th }}$ century $\mathrm{AD}$ the walls get figurative themes with human figures and horses. We don't know what scene was pictured here but the theme is inserted in the common trend from the $4^{\text {th }}$ century $\mathrm{AD}$, with scenes from the daily live of the great owners, often portrayed in banquets or hunting scenes. These scenes are very frequent in North African mosaics and they have one of the greatest expressions in Sicilian villa of Piazza Armerina (Pensabene 2014). This theme in the Sicilian mosaic becomes common in late Roman House, from North African influences, mainly from the $4^{\text {th }}$ century AD, extending these influences to the mural painting. In the case of Boca do Rio the fragments retrieved just allow us to distinguish the bust of a servant and the representation of a horse with rich harness (Fig. 14a-14b). These elements and other fragments of human
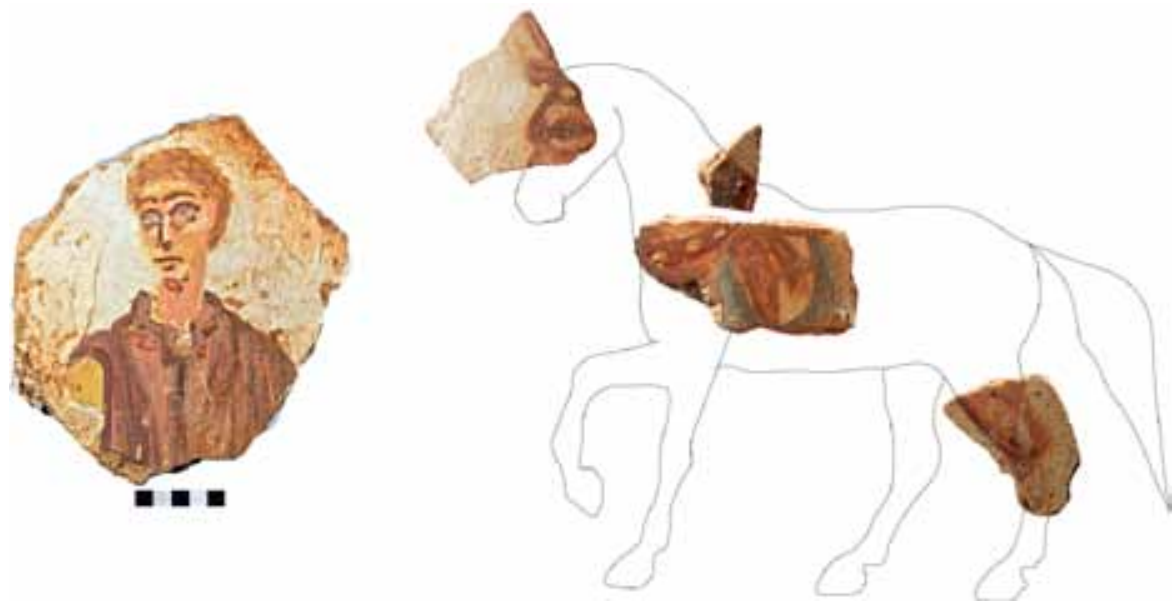
figures, refer to the possibility that we're faced the horse of someone of high social status, perhaps the dominus, recalling the hunting scenes of the mosaics of Piazza Armerina but also similar scenes in mosaics from Africa or Hispania (Blazquez 1994; Dunbabin 1999: 139-143).

\section{Conclusion}

We can see that the figurative mosaics of the Algarve have all a strong maritime connotation, which relates directly to the economy of the region. These decorative motifs are realistic, looking through the representation of a wide variety of elements and colors, depict marine life which supported much of the wealth of the region. And if this reality is common to villas, in Ossonoba, the main market town and port of the region, we continue to see in the figurative mosaics the presence of the sea. However, this time it's not the wealth of the sea and the marine fauna that represents, but before the Ocean god and the winds in a clear allusion to the mercantile and shipping activity. It is evident on these figurative mosaics a strong influence of North African artists, what is according with the archaeological reality. In fact, especially from the end of the second century $\mathrm{AD}$, the presence of ceramics and containers of amphorae of the current region of Tunisia is very significant and may represent about $1 / 3$ of the total of the amphorae in Algarve region (Viegas 2011: 561-567). This influence is still present in the painting of the maritime villa of Boca do Rio, where the Roman African ceramics, including the amphorae, are very frequent. In the murals fragments of the site are present human and equine motifs. Despite these fragments do not permit to reconstitute a scene, could correspond to the type of scenes, so frequent from the $4^{\text {th }}$ century $\mathrm{AD}$ in the villas, that represent and promote the activity and status of the owner. In the whole region of southern Portugal there is thus a great North African influence either on mosaics or in painting art. This relationship is already well known for ceramics, and results from the frequent maritime voyages between the East and the West, which facilitated the spread of the North Africans models in the Algarve region. These models arrived to the region appear to have been adapted in order to portray the local reality or to serve the likes of local owners.

\section{Bibliography - Kaynaklar}

Bernardes 2014 J. P. Bernardes, “Ossonoba E O Seu Território: As Transformações De Uma Cidade Portuária Do Sul Da Lusitânia”, D. Vaquerizo, J. A. Garriguet, A. Léon (eds.) Ciudad Y Territorio: Transformaciones Materiales E Ideológicas Entre Epoca Clásica Y El Altomedioevo. Monografías De Arqueología Cordobesa 20, 355-366.

Bernardes - Medeiros 2016 J. P. Bernardes - I. Medeiros, "Boca Do Rio (Budens, Vila Do Bispo): Novos Dados De Uma Villa Piscícola Romana”, Revista Portuguesa De Arqueologia 19, 265-286.

Campos Carrasco et al. 2008 M. Campos Carrasco - A Rota Do Mosaico Romano: O Sul Da Hispânia (Andaluzia E Algarve / La Ruta Del Mosaico Romano: El Sur De Hispania (Andalucia Y Algarve), Faro, Universidade Do Algarve.

Blázquez 1994

Dunbabin 1999

Lancha 1985

Lancha - Oliveira 2013

Mantas 1990
J. M. Blázquez, “El Entorno De Las Villas En Los Mosaicos De África E Hispania”, AfrRom 10, 1171-1187.

K. M. D. Dunbabin, Mosaics of the Greek and Roman World, Cambridge.

J. Lancha, “La Mosaique d'Océan Découverte A Faro”, Conimbriga 24, 151-175.

J. Lancha - C. Oliveira, Corpus Dos Mosaicos Romanos De Portugal / Corpus Des Mosaïques Romaines Du Portugal: II, Conventus Pacensis: 2, Algarve Este, Faro: Universidade Do Algarve.

V. Mantas, “As Cidades Marítimas Da Lusitânia”, In les Villes de Lusitanie Romaine, Hiérarchies Et Territoires, Coll. Maison Des Pays Ibériques 42, 149-205. 
Pensabene 2014

Santos 1971/1972

Teichner 2008

Viegas 2011

Viegas - Dinis 2010
P. Pensabene, "Pittura Tardoantica A Piazza Armerina: Gli Spazi Esterni E Le Tematiche Militari Come Autorappresentazione Del Dominus", N. Zimmermann (Hrsg.), Antike Malerei zwischen Lokalstil und Zeitstil, Akten des XI internationalen Kolloquium der AIRMA, Ephesos 2010, 148-155.

M. L. E. V. Santos, Arqueologia Romana Do Algarve, Vol. I / II, Lisboa, Associação Dos Arqueólogos Portugueses.

F. Teichner, Zwischen Land Und Meer - Entre Tierra Y Mar. Studien zur Architektur und Wirt-Schaftsweise ländlicher Siedlungen im Süden der römischen Provinz Lusitanien, Stvdia Lvsitana 3, Mérida, MNAR (2. vols.).

C. Viegas, A Ocupação Romana Do Algarve: Estudo Do Povoamento E Economia Do Algarve Central E Oriental No Período Romano, Estudos E Memórias 3, Lisboa, UNIARQ- Universidade De Lisboa.

C. Viegas - T. Dinis, “Pedras D’el Rei (Tavira): Villa Suburbana De Balsa”, Xelb 10, 235-251. 
